\title{
PERMASALAHAN GENDER DALAM \\ KASUS HUMAN IMMUNODEFICIENCY \\ VIRUS - ACQUIRED IMMUNODEFICIENCY \\ SYNDROME (HIV-AIDS) DI INDONESIA
}

\author{
Avin Ainur \\ Jurusan Fisika Fakultas Sains dan Teknologi UIN Maliki Malang \\ e-mail :avinainur@yahoo.com
}

\section{Abstract}

HIV-AIDS epidemic is a global crisis phenomenon and the hardest challenges for social development, particularly for underdevelopment countries. In general, people with HIV-AIDS are adults who are at the productive age and almost half are women. The National HIV-AIDS Prevention Commission stated that the number of housewives infected by $H I V$ continues to increase significantly every year. Conversely, the number of HIV infected people from commercial sex workers decreased. This is due to HIV transmission from their husband or intimate partners who have risky behavior. This condition concern an increase in the number of cases of HIV transmission from mother to child. HIV-AIDS problems are expected immediately handled and focused on the prevention of HIVAIDS on housewives. An attempt to strengthen human rights program on women's reproduction and improve women's bargaining power to resist high risk sexual relations must be implemented sustainably.

HIV-AIDS merupakan fenomena krisis global dan tantangan yang berat bagi pembangunan dan kemajuan social, terutama bagi negara-negara miskin. Pada umumnya, penderita HIV-AIDS adalah orang dewasa yang berada dalam usia produktifdan hampir separuhnya adalah wanita. Komisi Penanggulangan AIDS Nasional (KPAN) menyatakan bahwa jumlah ibu rumah tangga yang terinfeksi HIV di Indonesia terus meningkat secara signifikan setiap tahunnya, sebaliknya jumlah pekerja seks komersial yang terinfeksi HIV terus menurun. Hal tersebut disebabkan penularan HIV dari suami atau pasangan intim yang memiliki perilaku beresiko. Kondisi ini dikhawatirkan terjadi peningkatan jumlah kasus penularan dari ibu ke anak. Permasalahan HIV diharapkan dapat segera ditangani dengan 
baik dan difokuskan pada pencegahan HIV-AIDS pada ibu rumah tangga. Seharusnya terus dilakukan upaya memperkuat program-program hak asasi reproduksi perempuan dan meningkatkan kekuatan menawar wanita untuk menolak hubungan seksual beresiko tinggi.

Keywords : HIV-AIDS, ibu rumah tangga

\section{Pendahuluan}

InfeksiHumanImmunodeficiencyVirus-AcquiredImmunodeficiency Syndrome (HIV-AIDS) di Indonesia telah dilaporkan secara resmi sejak tahun 1987. Joint United Nations Programme on HIV-AIDS (UNAIDS) tahun 2005 memperkirakan ada sekitar 53.000-180.000 orang yang hidup dengan HIV dan AIDS di Indonesia. Menurut Departemen Kesehatan RI (2011) 78,8\% kasus yang dilaporkan berasal dari kalangan heteroseksual, dan sebanyak $77 \%$ kasus terjadi pada usia muda dan usia produktif, yakni pada kisaran usia 20-39 tahun.

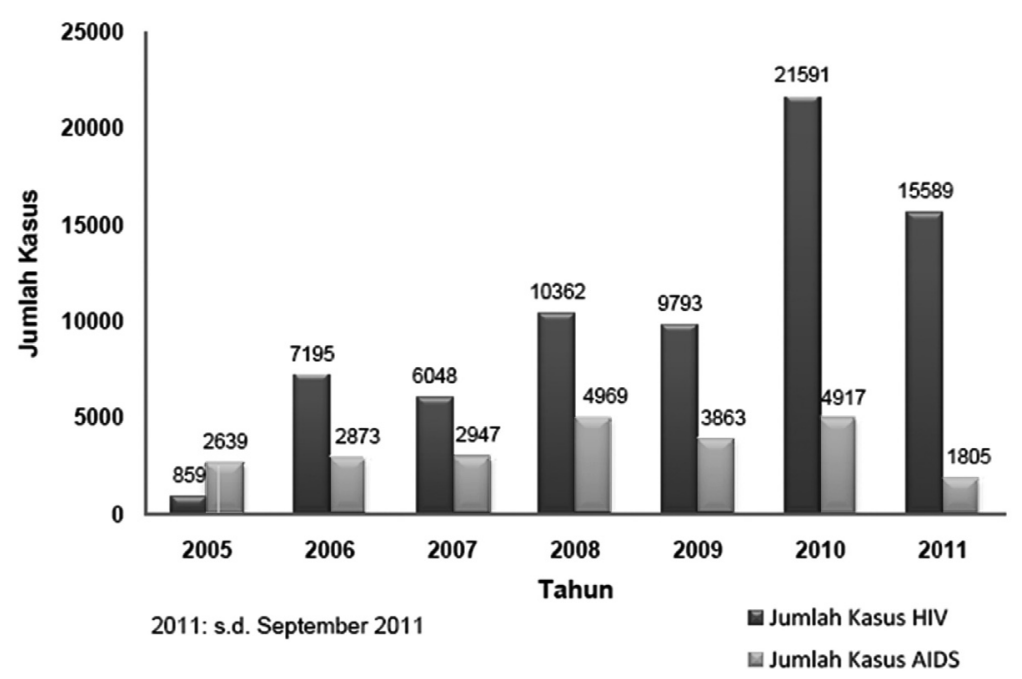

Gambar 10: Jumlah Kasus HIV-AIDS menurut tahun di Indonesia, 2005-2011

(Sumber : Kemenkes RI, 2011: 1) 


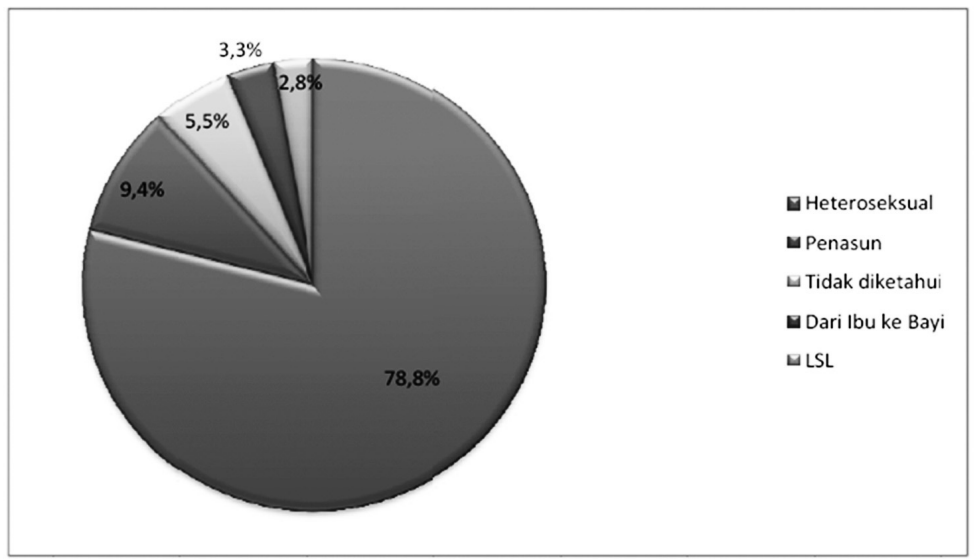

2011: s.d. September

Gambar 11: Proporsi Kasus HIV-AIDS Menurut Faktor Risiko Tahun 2011

(Sumber : Kemenkes RI, 2011:7)

Sama seperti kecenderungan di beberapa negara Asia lainnya (Cina, Thailand, Vietnam), HIV-AIDS di Indonesia adalah masalah generasi muda. Gambar 3 di bawah ini menunjukkan bahwa hampir $80 \%$ kasus yang dilaporkan ada pada mereka yang berusia di bawah 40 tahun, bahkan $60 \%$ di bawah 30 tahun. Kenyataan bahwa epidemi tersebut adalah masalah generasi muda sangat merisaukan, karena kelompok usia tersebut adalah kelompok produktif dan berpendidikan cukup tinggi. Jika kebutuhan kesehatan Orang Dengan HIV-AIDS (ODHA) tidak diperhatikan, maka kualitas hidup ODHA akan menurun drastis sejalan dengan perjalanan penyakit tersebut. Artinya, ketika infeksi itu menguasai tubuh ODHA, maka ODHA akan dirundung sakit dan tidak mungkin dapat berkontribusi pada keluarga dan masyarakatnya secara efektif (KPA, 2007:1). 


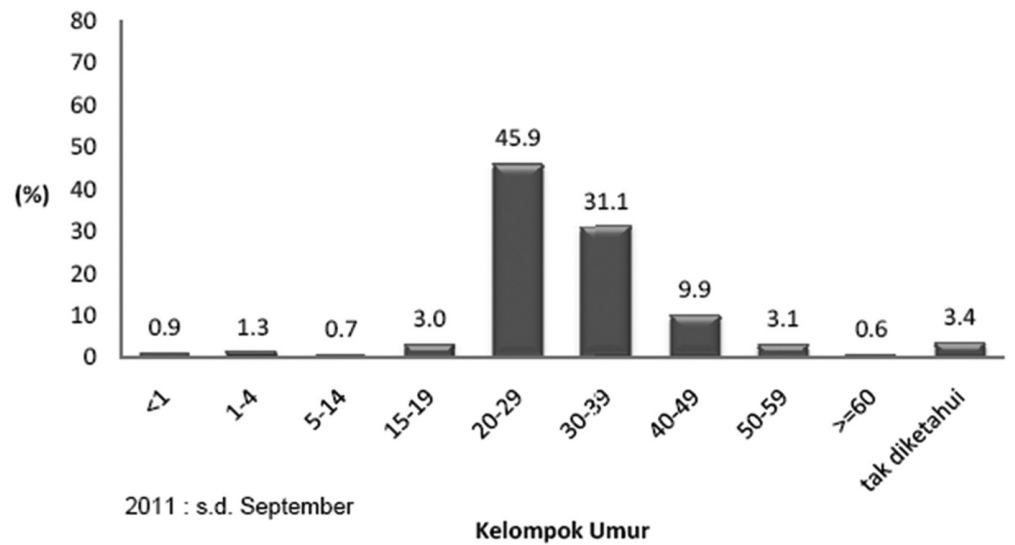

Gambar 12 : Proporsi Kumulatif Kasus HIV-AIDS menurut Kelompok Umur di Indonesia, 1987-2011 (Sumber: Kemenkes RI, 2011:2)

Berdasarkan laporan triwulan 3 tahun 2011 Direktorat Jenderal Pengendalian Penyakit dan Penyehatan Lingkungan, kasus HIV-AIDS berdasarkan pekerjaan didominasi oleh ibu rumah tangga, yaitu sebanyak 288 kasus.

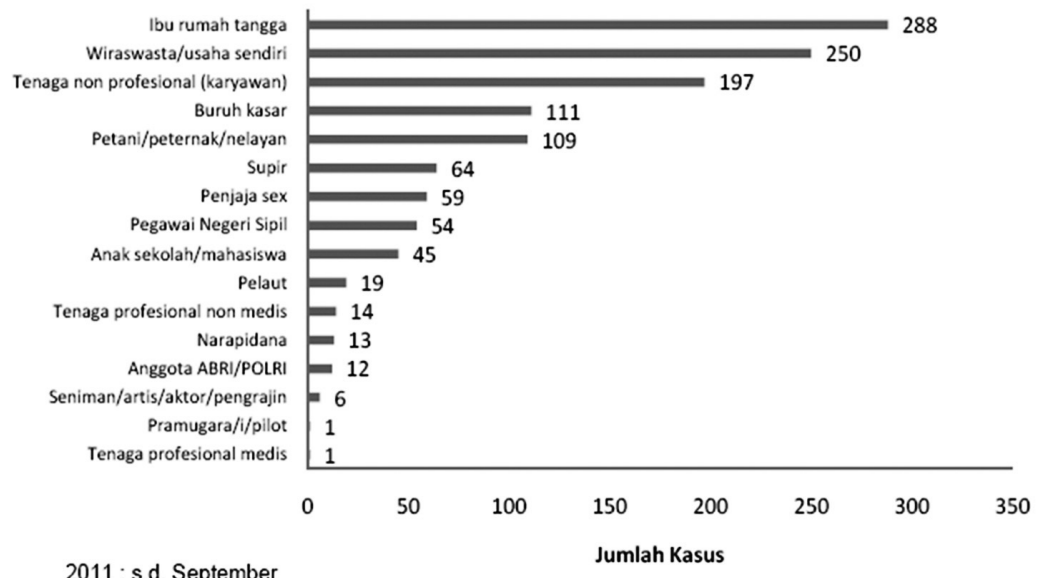

Gambar 13 : Jumlah Kasus AIDS menurut Pekerjaan di Indonesia Tahun 2011

(Sumber : Kemenkes RI, 2011: 4)

Menurut Kementerian Kesehatan, semakin rentannya perempuan di Indonesia terhadap penularan penyakit mematikan tersebut salah satunya disebabkan ketimpangan gender. Kerentanan perempuan terhadap 
HIV-AIDS ini lebih banyak disebabkan adanya ketimpangan gender yang berdampak pada ketidakmampuan perempuan mengontrol perilaku seksual suami serta kurangnya akses pelayanan pengobatan HIV-AIDS.

\section{Fakta-Fakta Tentang HIV-AIDS Struktur dan replikasi HIV}

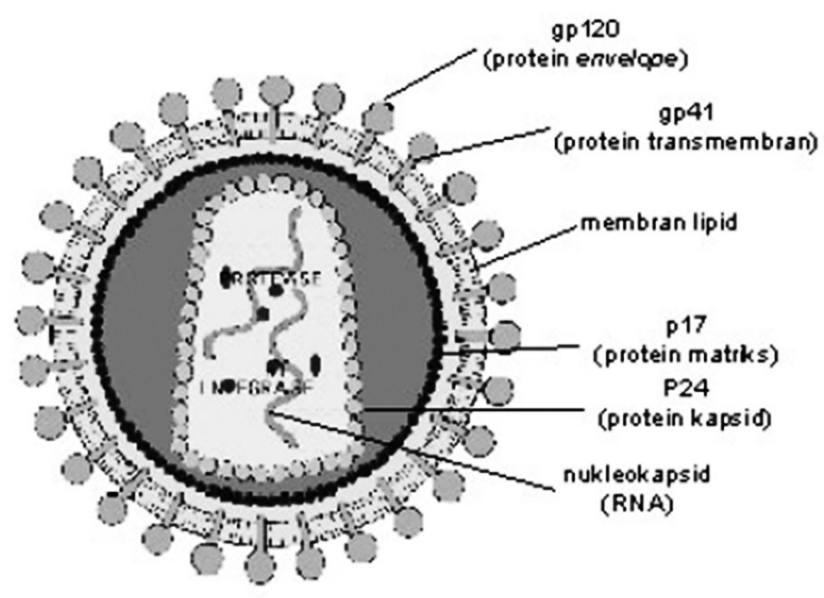

Gambar 14 : Struktur HIV

(Sumber : More about HIV, $2002: 2$ )

Bagian luar HIV diliputi oleh suatu selubung yang disebut envelope dan di bagian dalam terdapat sebuah inti (core). (Gambar 5)

- Envelope: HIV bergaris tengah 1/10.000 mm dan mempunyai bentuk bulat seperti bola. Lapisan paling luar disebut envelope, terdiri dari dua lapisan molekul lemak yang disebut lipids. Lapisan ini diambil dari sel manusia ketika partikel virus yang baru terbentuk dengan membentuk tonjolan dan lepas dari sel tersebut. Selubung virus terisi oleh protein yang berasal dari sel induk, termasuk 72 turunan (rata-rata) protein HIV kompleks yang menonjol dari permukaan selubung. Protein ini disebut Env, terdiri atas sebuah tutup (cap) terbuat dari 3-4 molekul glycoprotein (gp)120, dan sebuah batang yang terdiri atas 3-4 molekul gp41 sebagai rangka struktur dalam envelope virus. (Gunung, $2003: 21$ ) 
- Inti (Core): dalam envelope partikel HIV yang sudah matang terdapat inti berbentuk peluru yang disebut capsid, terbentuk dari 2000 turunan protein virus lainnya, p24. Capsid tersebut mengelilingi dua helaian tunggal RNA HIV, yang masing-masing memiliki 9 gen dari virus. Tiga di antaranya adalah: gag, pol dan env, mengandung informasi yang diperlukan untuk membuat protein terstruktur untuk partikel virus baru. Gen env, misalnya, mengkode protein gp160 yang dipecah oleh enzim virus untuk membentuk gp120 dan gp41, yang merupakan komponen Env. Tiga buah gen pengatur, tat, rev dan nef, dan tiga gen tambahan, vif, $v p r$ dan $v p u$, mengandung informasi yang diperlukan untuk memproduksi protein yang mengatur kemampuan HIV menginfeksi suatu sel, membuat turunan virus baru atau menimbulkan penyakit. Protein yang dikode oleh nef, misalnya, menyebabkan virus dapat melakukan replikasi secara efisien, dan protein yang dikode oleh $v p u$ berpengaruh terhadap pelepasan partikel virus baru dari sel yang diinfeksi. Ujung-ujung setiap helaian RNA HIV mengandung sebuah rangkaian RNA yang disebut LTR (long terminal repeat). (Gunung, 2003: 23)

\section{Replikasi HIV}

Infeksi dimulai saat partikel HIV menemukan sel Th (T-helper) dengan molekul permukaan yang disebut CD4. Partikel virus menggunakan gp120 untuk melekatkan dirinya pada membran sel, kemudian masuk ke dalam sel. Dalam sel partikel virus melepaskan RNA-nya, dan enzim reverse transcriptase kemudian mengubah RNA virus menjadi DNA. DNA HIV yang baru ini kemudian masuk ke dalam inti sel dan dengan bantuan enzim integrase dimasukkan ke dalam DNA sel host (sel yang diinfeksi). Begitu berada dalam gen DNA, DNA HIV ini disebut provirus. DNA mengalami transkripsi, DNA HIV dibaca untuk menghasilkan protein virus dalam bentuk rantai panjang. Selanjutnya protein virus menyatu dan membentuk kapsid (kapsul) dan membuat tonjolan pada dinding sel lalu melepaskan diri menjadi virus baru. HIV baru ini akhirnya mengalami maturasi (pematangan) dan siap menginfeksi sel-sel lainnya. (Gunung, 2003:24) 


\section{Tahap-tahap Penting Replikasi Virus:}

- Pelekatan (Attachment): HIV melekat pada sebuah sel (sel CD4).

- Peleburan (Fusion): HIV memasukkan bahan genetik (RNA, ribonucleic acid) ke dalam sel bersama beberapa enzimnya (protein) seperti reverse transcriptase, HIV protease (HIV protease) dan integrase.

- Bahan genetik HIV (RNA) diubah menjadi bahan genetik sel (DNA) untuk membuat turunan DNA. Langkah ini menggunakan enzim reverse transcriptase.

- Penggabungan (Integration): Turunan DNA ini masuk ke dalam inti yang mengandung bahan genetik sel dan bergabung dengan bahan genetik sel tersebut. Dalam langkah ini dipergunakan enzim integrase.

- Pembacaan dan penyalinan (transcription \& translation): Setelah penggabungan DNA virus dengan DNA sel, virus mengambil alih tugas sel, berubah menjadi pabrik penghasil virus.

- DNA virus membentuk cetakan yang diperlukan untuk membuat turunannya. Cetakan ini meliputi bahan genetik dan perintah membuat protein virus (genom virus).

- Genom virus membentuk kapsid, lalu membentuk tonjolan pada dinding sel dan melepaskan diri. Virus baru ini mengalami maturasi, memotong-motong DNAnya menjadi virus-virus baru yang siap menginfeksi sel-sel lainnya. Untuk memotong DNA virus tersebut dipergunakan enzim protease. (UNIFEM, 2004:16)

\section{HIV-AIDS}

HIV (Human Immunodeficiency virus), termasuk familia retrovirus. Sel-sel darah putih yang diserang oleh HIV pada penderita yang terinfeksi HIV adalah sel-sel limfosit T (CD4) yang berfungsi dalam sistem imun (kekebalan) tubuh. HIV memperbanyak diri dalam sel limfosit yang diinfeksinya dan merusak sel-sel tersebut, sehingga mengakibatkan sistem imun terganggu dan daya tahan tubuh berangsur-angsur menurun. Sebaliknya, akibat daya tahan tubuh yang melemah, mengakibatkan risiko 
timbulnya penyakit infeksi ataupun penyakit lain akan meningkat. Hal ini tidak akan terjadi dalam keadaan daya tahan tubuh yang normal. Infeksi yang timbul akibat daya tahan tubuh yang menurun itu disebut infeksi oportunistik. (Gunung, $2003: 26$ )

Ada dua tipe virus HIV yang penting, yaitu HIV-1 yang diidentifikasi pada tahun 1984 di Amerika Serikat dan HIV-2 yang diidentifikasi dari penderita AIDS di Afrika Barat pada tahun 1986. HIV-1 dan HIV-2 memiliki kesamaan dalam struktur, cara penularan, dan infeksi oportunistik yang menyertainya. Di samping itu, cara pencegahan dan penanggulangannya juga tidak berbeda, tetapi memiliki daerah penyebaran yang berbeda. HIV-2 jarang dijumpai di luar Afrika, dan memiliki masa inkubasi yang lebih panjang dibandingkan dengan HIV-1 (Gunung, 2003:27)

AIDS adalah singkatan dari Acquired Immunodeficiency Syndrome, merupakan sekumpulan gejala yang dijumpai pada fase akhir dari infeksi HIV. Gejala-gejala tersebut tergantung dari infeksi oportunistik yang menyertai infeksi HIV. Penurunan daya tahan tubuh akibat kerusakan sistem imun oleh HIV sampai pada tingkat timbulnya AIDS memerlukan waktu beberapa tahun (bisa sampai 15 tahun). Obat-obat antiretroviral dapat membantu mencegah perkembangan infeksi HIV menjadi AIDS, atau dapat memperbaiki kondisi penderita AIDS (Aditama, Y. 2007:14)

\section{Cara Penularan HIV-AIDS dapat Melalui :}

- Hubungan seksual tanpa menggunakan kondom. Hubungan seks melalui vagina dan anus mempunyai risiko yang tinggi, sedangkan hubungan seks oral mempunyai risiko yang rendah.

- Jarum suntik dan/atau spuit yang dipergunakan bersama untuk menyuntikkan obat-obatan atau steroid.

- Infeksi dari ibu hamil ke pada bayinya, saat melahirkan, atau sewaktu menyusui.

- Tusukan jarum yang terinfeksi HIV.

- Transfusi, olahan darah, atau transplantasi organ tubuh. Cara penularan ini sekarang jarang dijumpai di negara-negara maju, di mana semua donor darah dan organ telah dites HIV (Gunung, 2003:30) 


\section{Sifat-sifat HIV yang Berhubungan dengan Penularan}

Risiko penularan HIV dipengaruhi terutama oleh jumlah virus (viral load) yang ada di dalam cairan tubuh. Setiap orang yang terinfeksi HIV mempunyai potensi untuk menularkan HIV, meskipun viral loadnya tidak terdeteksi $\left(<50\right.$ turunan virus $\left./ \mathrm{mm}^{3}\right)$. Semakin tinggi viral load semakin besar potensi penularannya. Di samping itu ada faktor-faktor lain yang juga berpengaruh, seperti frekuensi hubungan, kekebalan tubuh dan lain-lain. Jumlah virus pada cairan tubuh sangat bervariasi. Beberapa jenis cairan tubuh mengandung virus dalam jumlah yang cukup banyak untuk bisa menularkan virus, seperti dalam darah, semen (carian air mani), cairan vagina dan serviks, air susu ibu, dan cairan dalam otak, sedangkan air kencing, air mata, keringat mengandung virus dalam jumlah kecil sehingga tidak mempunyai potensi penularan. Jumlah virus dalam tubuh orang dengan HIV-AIDS juga tidak menetap. Pada fase awal (stadium I), jumlah virus cukup banyak, sedangkan saat tubuh mulai membentuk antibodi jumlah virus akan menurun dalam darah (WHO-ILO. 2005: 26)

Dalamsuatuhubungan seks, selainjumlah virus, frekuensihubungan, jenis hubungan, faktor host juga memegang peran. HIV mempunyai kemampuan menular sangat rendah dibandingkan dengan kuman/virus lain yang menular melalui hubungan seks (gonore, klamidia, sifilis dan lain-lainnya). Dalam satu hubungan seks, kemungkinan penularannya sekitar 5-15\%. Walaupun demikian, fakta yang ada menunjukkan ternyata HIV mampu untuk menembus jaringan lunak yang sehat pada permukaan dalam dubur maupun serviks, sebelumnya HIV diperkirakan hanya bisa menembus jaringan yang sakit (meradang) saja. Dengan demikian pasangan seks yang tergolong risiko rendah juga dapat terinfeksi. Dalam keadaan ini diperkirakan penularan HIV melalui sel-sel pada saluran kencing ataupun kulit yang menutup penis (bila tidak disirkumsisi). Jadi, laki-laki yang tidak disirkumsisi mempunyai risiko yang lebih tinggi untuk tertular HIV dalam suatu hubungan dengan pengidap HIV. Adanya infeksi menular seksual (IMS) yang lain (misal Gonorrhoe, klamidia), dapat meningkatkan risiko penularan HIV (2-5\%). IMS ternyata dapat meningkatkan jumlah HIV pada cairan semen ataupun vagina sehingga mempunyai potensi penularan lebih besar (Aditama, 2001:28). 


\section{Gejala Infeksi HIV-AIDS}

Infeksi HIV dapat dibagi menjadi 3 stadium, yaitu: infeksi akut, kronik, dan AIDS.

- Infeksi akut, merupakan stadium paling dini dan singkat. Tidak semua penderita menunjukkan gejala-gejala, tapi kebanyakan menunjukkan gejala-gejala seperti flu selama 3-6 minggu setelah infeksi. Gejala-gejalanya sama dengan flu atau mononukleosis: panas dan rasa lelah yang berlangsung selama 1-2 minggu. Bisa disertai ataupun tidak gejala-gejala seperti:

- Bisul dengan bercak kemerahan, biasanya pada tubuh bagian atas, tidak gatal.

- Sakit kepala.

- Sakit pada otot-otot.

- Sakit tenggorokan.

- Pembengkaan kelenjar.

- Diare (mencret).

- Mual-mual.

- Muntah-muntah.

Tes HIV yang sensitif dapat menjelaskan apakah seseorang terinfeksi HIV akut atau tidak. Pengobatan pada stadium akut dengan obat antiretroviral jauh lebih baik dibanding stadium yang lebih lanjut. Tes HIV yang biasa tidak dapat mendeteksi infeksi yang akut. (Gunung, 2003:32)

- Infeksi HIV kronik. Infeksi kronik ini mulai 3-6 minggu setelah infeksi. Pada stadium ini tidak menunjukkan gejala apapun, seperti orang sehat. Pada umumnya, pada kebanyakan penderita, stadium ini berlangsung sampai 10 tahun. Walaupun tidak menunjukkan gejala-gejala, akan tetapi sistem imun berangsur-angsur menurun. Pada orang normal, didapatkan sel CD4 sebesar 450-1200 sel per ml. Bila sel CD4 menurun sampai 200 atau kurang, maka penderita akan masuk dalam stadium AIDS (Gunung, 2003:33)

- Gejala AIDS. AIDS merupakan sekumpulan gejala-gejala yang menyertai infeksi HIV tersebut. Oleh karena sistem imun telah rusak, gejala-gejala penyakit menjadi khas tergantung jenis infeksi 
yang menyertainya. Obat diberikan bila sel T (CD4) turun sangat rendah untuk mencegah terjadinya infeksi.

Gejala-gejala yang bisa dijumpai adalah:

- Selalu merasa lelah.

- Pembengkakan kelenjar pada leher atau lipatan paha.

- Panas yang berlangsung lebih dari 10 hari.

- Keringat malam.

- Penurunan berat badan yang tidak bisa dijelaskan penyebabnya.

- Bercak keunguan pada kulit yang tidak hilang-hilang.

- Pernafasan memendek.

- Diare berat, berlangsung lama.

- Infeksi jamur (candida) pada mulut, tenggorokan, atau vagina.

- Mudah memar/perdarahan yang tidak bisa dijelaskan penyebabnya (Gunung, 2003:35)

\section{Pencegahan HIV-AIDS}

Kegiatan pencegahan meliputi upaya pencegahan baik melalui jalur hubungan seksual, jarum suntik yang dipakai bersama oleh pengguna narkoba suntikan, maupun upaya pencegahan penularan dari ibu hamil HIV positif ke bayinya. Upaya pencegahan penularan di kalangan layanan kesehatan dilaksanakan dengan mengamalkan kewaspadaan universal (Kemenkes, 2007:47)

Upaya pencegahan harus terkait dalam perawatan, yang meliputi kegiatan:

a. Penyuluhan

Berbagai upaya penyuluhan dengan komuniksasi, informasi dan edukasi diharapkan dapat menyadarkan masyarakat tentang pentingnya memahami cara penularan serta melindungi diri dan keluarga dari penularan HIV-AIDS. Ini berarti menumbuhkan gaya hidup sehat serta meninggalkan perilaku berisiko. Selain itu masyarakat juga perlu menyadari pentingnya mengetahui status HIV terutama bagi mereka yang pernah melakukan perilaku berisiko atau berisiko tertular dari pasangan. Upaya penyuluhan ini 
perlu dilaksanakan pada tingkat keluarga, sekolah dan masyarakat. (Kemenkes, 2007:48)

b. Promosi kondom dan perilaku seksual yang lebih aman.

Infeksi menular seksual dapat meningkatkan risiko HIV secara nyata karena itu upaya pencegahan infeksi menular seksual amat penting dilakukan. Penggunaan kondom di lokalisasi yang diharapkan dapat mencapai $50 \%$ sampai saat ini belum tercapai. Begitu pula diagnosis dan terapi infeksi menular seksual perlu dipertajam sehingga penyakit ini dapat dikurang seminimal mungkin di masyarakat. (Kemenkes, 2007:48)

c. Pengurangan dampak buruk bagi para penasun, seperti pertukaran alat suntik steril, terapi rumatan metadon oral

d. Penerapan kewaspadaan universal

e. Profilaksis pasca pajanan

f. Pencegahan penularan dari ibu ke anak

Dengan semakin banyaknya orang perempuan yang dalam rentang usia subur terinfeksi HIV maka angka kekerapan HIV di kalangan ibu hamil akan meningkat. Kesempatan untuk mencegah penularan pada bayi yang dikandung harus dimanfaatkan dengan baik.

(Aditama, 2003:39)

g. Layanan Transfusi Darah yang Aman

Upaya untuk mencegah penularan HIV melalui jalur transfusi darah ini telah dimulai sejak tahun 1992 dengan melakukan skrining darah yang akan ditransfusikan. Namun kebutuhan darah mendadak di daerah yang belum mempunyai layanan transfusi darah dapat berisiko penularan HIV karena transfusi darah tidak dilaksanakan secara darurat dan tidak disertai skrining HIV (Gunung, 2003:39)

\section{Permasalahan Gender}

Di Indonesia, permasalahan gender masih menjadi persoalan, dan diperkirakan jumlah perempuan yang terdeteksi virus HIV akan terus meningkat, karena penyebab utamanya adalah penularan dari suami ke istri mereka. Ketimpangan gender itu telah membuat posisi tawar perempuan sangat rendah dalam pengambilan keputusan termasuk aspek kesehatan 
reproduksinya. (Carr, 2008:4)

Dalam banyak kasus, para ibu rumah tangga tertular dari suaminya yang sudah lebih dahulu terpapar HIV-AIDS karena kerap berganti pasangan atau menggunakan jarum suntik saat mengonsumsi narkoba. Di lain pihak, sebanyak $40 \%$ pria dengan HIV positif tetap berhubungan dengan pasangannya ( Carr, 2008:6). Dengan fakta ini, otomatis makin banyak jumlah yang tertular HIV-AIDS dari ibu rumah tangga dan setiap tahun jumlahnya terus mengalami peningkatan. Tercatat sejak 2008 jumlah penularan di kalangan ibu rumah tangga naik dari tahun ke tahun, pada 2008 terjadi $26 \%$ angka penularan,jumlah ini meningkat pada 2009 menjadi 27\%, kemudian pada 2010 meningkat lagi menjadi 31,49\%,dan pada 2011 jumlahnya menjadi 39,23\% ibu yang terinfeksi (UNIFEM, 2002:5).

Berdasarkan Declaration of Commitment on HIV-AIDS, United Nations General Assembly Special Session on HIV-AIDS pada Juni 2001, banyaknya kejadian HIV-AIDS di kalangan perempuan karena:

- Kemiskinan, kebodohan, dan status sosial yang rendah membuat perempuan menjadi sasaran tindakan kekerasan, trafficking, dan eksploitasi seksual

- Posisi tawar perempuan yang rendah, sehingga tidak bisa menentukan seks yang aman dan menolak seks yang tidak diinginkan

- Kekerasan seksual dan eksploitasi seksual terutama pada situasi konflik

Stigma masyarakat selama ini menganggap bahwa HIV-AIDS hanya dialami perempuan penjaja seks komersial (PSK) tidak benar karena perempuan yang tidak berperilaku berisiko juga dapat terinfeksi HIV yang ditularkan suami yang berhubungan seksual dengan orang yang terkena HIV-AIDS (UNIFEM, 2009:3). Menurut A Joint Report by UNAIDS / UNFPA / UNIFEM tahun 2004, kesetaraan gender dalam keluarga dan masyarakat akan dapat mengeliminasi kerentanan perempuan terhadap HIV-AIDS karena dengan demikian perempuan akan dapat membuat keputusan sendiri mengenai aktivitas seksualnya. Banyak perempuan menjadi rentan karena perilaku beresiko dari orang-orang terdekatnya. Di sinilah pentingnya upaya meningkatkan posisi tawar perempuan sehingga mampu mandiri dalam memutuskan hak-hak reproduksinya. 


\section{Kesimpulan}

Peningkatan jumlah penderita HIV-AIDS dikalangan ibu rumah tangga yang semakin meningkat disebabkan penularan HIV dari suami atau pasangan intim yang memiliki perilaku beresiko. Adanya ketimpangan gender membuat posisi tawar-menawar perempuan sangat rendah, sehingga tidak bisa menentukan seks yang aman dan menolak seks yang tidak diinginkan. Sehingga diperlukan upaya meningkatkan posisi perempuan sehingga mampu mandiri dalam menentukan hak-hak reproduksinya.

\section{DAFTAR PUSTAKA}

A Joint Report by UNAIDS / UNFPA / UNIFEM. 2004. Women and HIVAIDS: Confronting the Crisis

Aditama, T. 2001. Panduan Tatalaksana Klinis Infeksi HIV pada orang Dewasa dan Remaja. Departemen Kesehatan Republik Indonesia Direktorat Jenderal Pengendalian Penyakit dan Penyehatan Lingkungan

Carr, R. 2008. Promoting Gender Equality in HIV and AIDS Responses: Making Aid More Effective Through Tracking Results. United Nations Development Fund for Women (UNIFEM)

Drezin, J. 2009. Together We must end Violence Against Women and Girls and HIV-AIDS. United Nations Development Fund for Women (UNIFEM)

Gunung. 2003. Buku Pegangan Konselor HIV-AIDS. Macfarlane Burnet Institute for Medical Research and Public Health Limited

Kemenkes RI. 2011. Laporan Kasus HIV-AIDS di Indonesia. Triwulan 3 Tahun 2011. Direktorat Jenderal Pengendalian Penyakit dan Penyehatan Lingkungan. Kementerian Kesehatan RI

Kemenkes. 2007. Pedoman Pengembangan Jejaring Layanan Dukungan dan Perawatan dan Pengobatan HIV-AIDS. Dirjen Pengendalian Penyakit dan Penyehatan Lingkungan.

KPA. 2007. ODHA dan Akses Pelayanan Kesehatan Dasar. Penelitian Partisipatif. WHO \& UNAIDS 
KPA. 2003. Strategi Nasional Penanggulangan HIV-AIDS 2003-2007. Jakarta: Kementerian Koordinator Bidang Kesejahteraan Rakyat. Komisi Nasional Penanggulangan AIDS.

MAP (2004). AIDS in Asia: Face the Facts. A Comprehensive Analysis of the AIDS Epidemics in Asia. MAP Report.

More About HIV. 2002. Virion Structure. http://biology.fullerton.edu/ courses/biol_302/Web/Browser/moreabout.html.Akses: 2 Januari 2012

UNIFEM. 2002. Act Now: A Resource Guide for Young Women on HIV/ AID. United Nations Development Fund for Women (UNIFEM)

UNIFEM.2004.Transforming the NationalAIDSResponse: Mainstreaming Gender Equality and Women's Human Rights into The "Three Ones"

WHO-ILO. 2005. Pedoman bersama ILO/WHO tentang Pelayanan Kesehatan dan HIV-AIDS. Terjemahan oleh Zulmiar Yanri. Dirjen Pembinaan Pengawasan Ketenagakerjaan Departemen Tenaga Kerja dan Transmigrasi RI 